\title{
Storage Biologically Active Substances by Convection Drying Food and Medicinal Plants
}

\author{
Norkulova Karima, Safarov Jasur and Sultanova Shaxnoza*
}

Tashkent State Technical University, Tashkent, Republic of Uzbekistan

\begin{abstract}
The paper presents the overview and experimental results, and recommendations for drying herbs with quality preservation of biologically active substances and their application in the food and pharmaceutical industries. Dehydration of products are widely used since ancient times, the earliest known drying of 12,000 BC inhabitants of the modern Middle East and Asian regions. With the aid of drying suppressed the growth of bacteria, yeasts and mold by removing water. A properly chosen drying method allows you to save the dried final product active biological substances with maximum preservation. This study is an overall view of the conveyor of the dryer, which proposes to carry out drying of forest products.
\end{abstract}

Keywords: Medicinal plants; Drying; Food; Convection; Methods; Active biological substances; Herbs; Pumpkin

\section{Introduction}

\section{Drying of raw materials: a method of dehydration in various ways}

Dehydration products are widely used since ancient times, the earliest known drying of 12,000 BC inhabitants of the modern Middle East and Asian regions. With the aid of drying suppressed the growth of bacteria, yeasts and molds by removing water. A properly fitted drying method allows you to save the dried final product active biological substances with maximum preservation. Drying of foods is an important method for the food and pharmaceutical industries and offers new opportunities for development, as well for consumers. In recent years there have been many advances in the field of engineering and technology related to industrial drying of foods, including pretreatment technology, equipment and quality of the dehydrated product.

\section{Objects and Methods}

Has historically developed so, that the sun drying and hot air drying, ie. Convective drying was the most common method for drying foods. Solar drying is a cheap and traditional way, but its application is dependent on weather conditions and requires more processing space. Also, it is necessary to protect the raw from insects and small animals as well as from contact with airborne dirt. In convection drying can be to control these adverse factors and to increase the average drying rate. In addition, when using certain methods and modes of drying the resulting final product retains all the beneficial properties and biological active substances [1]. For many centuries herbs have been used by our ancestors to treat many illnesses. Modern medicine has made a big step forward in its development and at the moment there are so many different medications that can cure any disease. But the basic treatment can supplement traditional methods in order to achieve greater effect. Recipes used in folk medicine, is to use mainly medicinal plants. Namely they can be rightfully considered the most valuable treasure that nature has given us. For the preparation of infusions, tinctures and other formulations for the treatment of various illnesses common to use roots, fruits and leaves of various herbs. The effectiveness of such tools tested by generations of people, and today we know many recipes to help heal the body, cure disease and enhance human immunity. Medicinal plants-the most available means for everyone, because it grows right under your feet. Herbs are indispensable in the treatment of diseases and in addition, they are much safer than all modern synthetic drugs as almost do not cause any adverse effects.

Usually of harvested herbs are dried. Only some of them (Landysh, fern) are sometimes used in a fresh state. But these cases are like the exception to the general procedure for the use of medicinal plants. In the world of medicine quite widely disseminating the drying herbs and raw materials for further use in the manufacture of medicines. Unfortunately, the recommended method of blanks is taking too long, that medicine alone cannot afford. And if we apply the high temperatures during drying, the plants lose their healing qualities [2]. Studies have shown that heating plants to temperatures above $50^{\circ} \mathrm{C}$, enzymes work considerably weakened, and often stops altogether. Meanwhile, such a temperature causes disintegration of many active substances. In the presence of moisture of $10-14 \%$ enzyme activity is converted, i.e. starting chemical processes that lead to loss of biological raw substances in metamorphosis transformation. Raw material which contains cardiac glycosides, alkaloids, must be dried at a temperature of regulatory $55^{\circ} \mathrm{C}$ to $60^{\circ} \mathrm{C}$, and the matter containing essential oil was dried at $25^{\circ} \mathrm{C}$ to $35^{\circ} \mathrm{C}$. In view of this, for best results, the drying should be generally faster and performed at a temperature of $40^{\circ} \mathrm{C}$ to $50^{\circ} \mathrm{C}$. However for certain groups of plants, this temperature is high and causes a partial or complete vaporization of volatile active ingredients. These herbs first of all relate ether containing plants. Experiments conducted with these plants showed that the slow drying in a thick layer at a temperature above $30^{\circ} \mathrm{C}$ to $35^{\circ} \mathrm{C}$, the amount of essential oils (e.g., peppermint leaves) is not reduced. Drying is at a temperature of $40^{\circ} \mathrm{C}$ to $50^{\circ} \mathrm{C}$. rapidly decreases the amount of essential oils and can give, although outwardly beautiful but low-value material with a negligible content of essential oil. In recent years, the diet of modern man sharply reduced the amount of natural food that cannot provide the human organism with all necessary nutrients. Uzbekistan

*Corresponding author: Sultanova Shaxnoza, Tashkent State Technical University, Tashkent 100095, Republic of Uzbekistan, Tel: +998-94-563-0508; E-mail: sh.sultanova@mail.ru

Received May 20, 2016; Accepted June 09, 2016; Published June 15, 2016

Citation: Karima N, Jasur S, Shaxnoza S (2016) Storage Biologically Active Substances by Convection Drying Food and Medicinal Plants. J Food Process Technol 7: 599. doi:10.4172/2157-7110.1000599

Copyright: ( $) 2016$ Karima N, et al. This is an open-access article distributed unde the terms of the Creative Commons Attribution License, which permits unrestricted use, distribution, and reproduction in any medium, provided the original author and source are credited. 
and other countries the issues of population of food products and dietary supplements are especially important and significant part of the population suffers from a lack of many vitamins, minerals and the extremely necessary for human life. Pumpkin is a sort of natural vitamin mineral complex. Champion among the vitamins contained in the pumpkin is beta-carotene, pumpkin is rich in vitamins $\mathrm{C}, \mathrm{E}, \mathrm{B}, \mathrm{B}$, RR.V, lot of potassium, calcium, iron, magnesium, copper, zinc, cobalt, silicon, fluorine. Pumpkin is one of the most widely grown vegetables are incredibly rich in essential vitamins and antioxidants. Pumpkin has a number of useful properties. Despite the fact that $90 \%$ pumpkin consists of water, it is a good source of carotene, vitamins, especially should be borne in mind people suffering from cardiovascular diseases. Besides pumpkin is low-calorie and high in fiber. By the number of pumpkins are close to the carotene of carrots. Pumpkin seeds are also useful; they contain fats, proteins, vitamins and mineral salts.

Particularly rich in vitamin E, helps against premature aging and zinc salts, which are necessary for normal development of the male organism. Pumpkin is one of the most widely grown vegetables are incredibly rich in essential vitamins and antioxidants. Although this modest vegetable backyard few calories, but nonetheless it contains vitamin A, flavonoids and poly-phenolic antioxidants such as lutein, xanthin and carotene in abundance. According to the content of iron pumpkin surpasses the best varieties of apples. This is one of the most popular field crops cultivated worldwide, including Uzbekistan industrially for its fruits and seeds for various uses food and pharmaceutical industry. Vitamin A is a powerful natural antioxidant and is necessary an organism for maintaining integrity of the skin and mucous membranes. In addition, it is an essential vitamin for good vision even in old age. Studies have shown the use of natural foods rich in vitamin A may help protect the body from lung cancer and cancer of the oral cavity $[3,4]$.

\section{Results and Discussion}

Recent studies of the authors have shown that the new drying approaches, such as convective or combined method with infrared (IR) rays with the assistance of drying can currently be taken to improve the efficiency and drying efficiency, so that power consumption can be reduced while both at the same time maintaining the quality of the final product. Currently work highlights the latest developments of new drying techniques to ensure sustainability in the food industry and points to the side.

Figure 1 is a perspective view of a conveyor dryer, which proposes to carry out drying of forest products and some melons like a pumpkin. Figures 2 and 3 shows the results of comparisons of the technology with thicknesses between convective drying the drying object-pumpkin that for $160 \mathrm{~min}$ at moisture content of 5-6 mm thickness of the material decreases from 76 to $25 \%$ and at a thickness of $3 \%$ to $3.5 \%$ to $9 \mathrm{~mm}$.

Besides implementation of the process of drying of medicinal plants is carried out according to the following technologies, take freshly cut plant material from medicinal herbs, sort of weeds, cleaned of dust and other contaminants. Disintegrators cut into $5 \mathrm{~cm}$ and languishes the shade open air for 1-2 hours to reduce the initial moisture content. To preserve the biologically active substances exclude direct sunlight. Before drying sliced herbs uniformly placed in stainless mesh trays, each with a floor area of $0.9 \mathrm{~m}^{2}$ and a depth of $5 \mathrm{~cm}$. A load of $225 \mathrm{~kg}$ to 300 $\mathrm{kg}$, an average of $270 \mathrm{~kg}$ of raw herb. The drying process is performed by herbs heating medium feed (bottom-up) with a temperature of $45^{\circ} \mathrm{C}$ $-55^{\circ} \mathrm{C}$ for $120-180$ minutes. As the coolant used hot air, which is fed from the outside. The use as fuel gas or solid fuel consumed per batch of $4 \mathrm{~m}^{3}$ gas. Performance is subject to the $2000 \mathrm{~kg} /$ day. For convective drying pumpkins and herbs authors have developed a few rules and

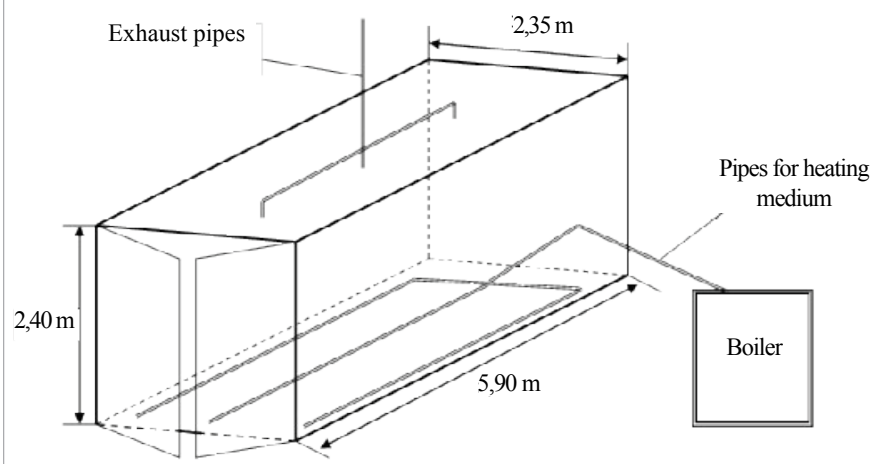

Figure 1: General view of a conveyor dryer.

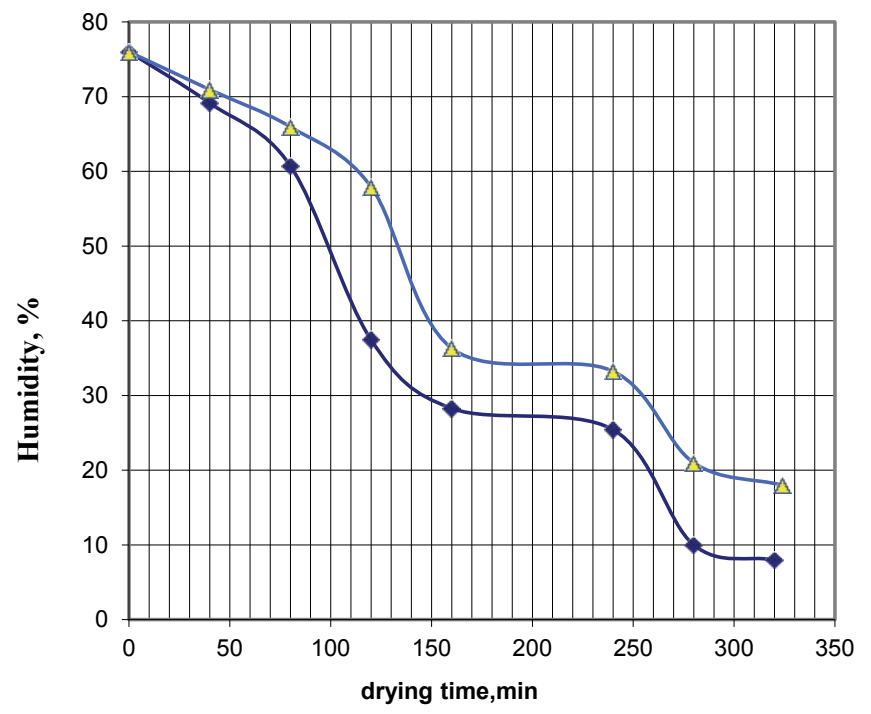

Figure 2: Curves of drying pumpkin with different layer thicknesses.

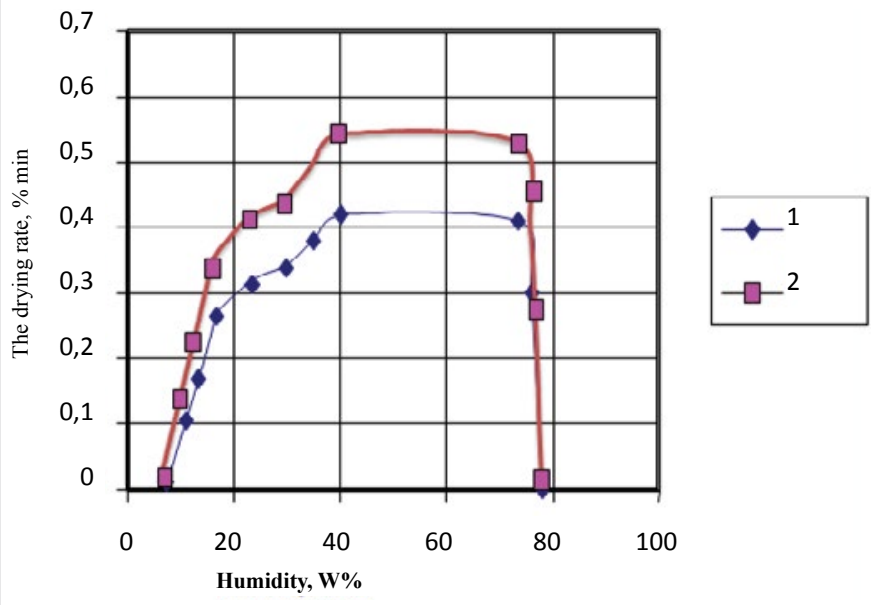

Figure 3: Pumpkin drying curve speed (1: at a thickness of 5-6 mm layer; 2: 3-3.5 $\mathrm{mm}$ layer with a thickness). 
Citation: Karima N, Jasur S, Shaxnoza S (2016) Storage Biologically Active Substances by Convection Drying Food and Medicinal Plants. J Food Process Technol 7: 599. doi:10.4172/2157-7110.1000599

Page 3 of 3

recommendations on the basis of repeated experiments and analyze:

a. Raw material which contains oils, dried at a temperature of $30^{\circ} \mathrm{C}$ to $35^{\circ} \mathrm{C}$ in the $10 \mathrm{~cm}-16 \mathrm{~cm}$ layer to prevent evaporation of the essential oils.

b. Raw material which contains glycosides, $50^{\circ} \mathrm{C}$ to $60^{\circ} \mathrm{C}$. This allows you to quickly inactivate the enzymes that destroy glycosides.

c. Raw material which contains alkaloids, $50^{\circ} \mathrm{C}$

d. Raw material which contains ascorbic acid, $55^{\circ} \mathrm{C}$ to $65^{\circ} \mathrm{C}$.

The yield of dry product depends on the nature of the feedstock. Freshly harvested herbs or parts thereof contain $40-95 \%$ moisture; finished dried product has a moisture content of not more than 10$18 \%$. Thus, the magnitude of the loss of water will range from $40 \%$ to $85 \%$, depending on the type of product. We can assume that when dried leaves lost $80 \%$ on average, i.e. $100 \mathrm{~kg}$ of raw sheet we will get $20 \mathrm{~kg}$ of dry herb-70\%, for colors $75 \%$, for the roots $65 \%$, for the crust are $40 \%$. Good dried saponin must contain hygroscopic Moisture not more than $12 \%-15 \%$. Table 1 shows the output of the finished raw material after drying.

\section{Conclusion}

Each of the methods of drying plant raw herbs attar addition, it is necessary to expand a thin layer, and then inverted regularly. You should also seek to minimize the degree of grinding of raw materials. The resulting end products retain their useful properties, biologically

\begin{tabular}{|c|c|}
\hline Name of raw materials & Exit, \% \\
\hline The roots and rhizomes & $22-32$ \\
\hline Herbs & \\
\hline Succulent (mint, ziziphora) & $20-25$ \\
\hline Not succulent (periwinkle) & $36-50$ \\
\hline Leaves & \\
\hline Succulent (cowslip, strawberry) & $15-22$ \\
\hline Not succulent (primrose, wild strawberry) & $45-50$ \\
\hline Flowers and inflorescences & $14-22$ \\
\hline Fruit & $13-18$ \\
\hline Succulent (barberry) & $25-35$ \\
\hline Dry (hawthorn) & 40 \\
\hline Bark & \\
\hline
\end{tabular}

Table 1: Exit after drying of raw materials.

active substances and look at the correct observance of the above recommendations on the technology of drying foods and medicinal herbs.

\section{References}

1. Atanazevich VI (2000) Drying of foods. UIUC, New Delhi.

2. Sangajievich SI (2011) On the basic laws governing the process of convective drying of fruits and seeds. J Astrakhan Techni univer.

3. Safarov JE, Sultanova SA, Saidova NX (2016) Technology of convection drying of medicinal plants. II International Scientific and Practical Conference: Innovative Technologies in Science, Dubai, UAE.

4. Safarov JE, Abdurahmanova ZA, Sultanova SH (2015) A method of processing medicinal herbs. Innovation-2015, San Jose Marriott, CA, USA. 